\title{
Evolution, Conceptualization and Legal limplications of Social Rights
}

\section{JOSÉ LUIS CORONA LISBOA ${ }^{1,2 *}$ and MARIZÉ DAMARIS MIJARES HERNÁNDEZ ${ }^{3}$}

\author{
${ }^{1}$ Nathional Experimental Francisco of Miranda, Venezuela. \\ ${ }^{2}$ Research and Postgraduate Department, Panamerican Center \\ for Higher Studies, Heroica Zitácuaro, México. \\ ${ }^{3}$ Simón Bolívar University, Caracas. Venezuela.
}

\begin{abstract}
This document constitutes a review article where the antecedents, concepts, classification and importance of fundamental social rights in the world of Law and for a contemporary society in search of the vindication of human dignity as a way of life and sustainability are exposed. The methodology used was exhaustive documentary research, where a review and classification of the most interesting articles on the subject was made, where the opinion of the cited researchers and the author's own ideas are exposed. It is concluded that fundamental social rights are essential to establish legal-social mechanisms in favor of social coexistence and the promotion of life as the backbone of society.
\end{abstract}

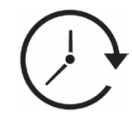

Article History

Received: 27 August 2020 Accepted: 25 November 2020

\section{Keywords}

Law;

Man;

Social Law;

Society.

\section{Introduction}

The right; It is a doctrine that philosophical, legislative, religious and social bases seek the organization of society as a charitable state with duties and assets attributable to all citizens without any distinction, where ethics must be the transversal axis to avoid inequalities in the application of the laws, decrees and regulations emanating from it.

From the universal sphere, we find two types of law: fundamental and social. Fundamental rights, has its origin in France at the end of the $18^{\text {th }}$ century and refers to that doctrine that establishes that man by his very nature, unique, unrepeatable and unequaled has the right to guarantees that result in his harmonic subsystem in the human ecosystem, without prejudice to their political, religious, race, sexual orientation, among others. Being the dignity of the human being, equality and freedom, the pillars that support this right., ${ }^{1,2}$

In addition, the fundamental rights that are above the rights of the State, and the State must ensure compliance with them for the benefit of man.

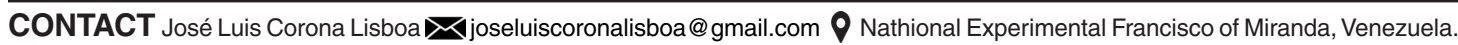
(c) (i)

(C) 2020 The Author(s). Published by Enviro Research Publishers.

This is an Open Access article licensed under a Creative Commons license: Attribution 4.0 International (CC-BY).

Doi: http://dx.doi.org/10.12944/CRJSSH.3.2.05 
An example of them are: the right to life, the right to food, among others. This is a hierarchical legislative and social way that establishes in a categorical and well-determined way, the importance of man as an essential entity for the development of humanity, as the forming cell of the social fabric. ${ }^{3}$

The fundamental right of all human beings has spread even further during the $20^{\text {th }}$ and $21^{\text {st }}$ centuries, as a result of social pressures on autocratic regimes and the absolutist bureaucracy characteristic of State systems incapable of solving in a democratic and decentralized way the current problems of society, to name a few: the right to decent work, own home, and so on.

In this sense, non-governmental organizations such as the United Nations, the International Court of Human Rights and other indigenous civil associations from the various countries of the world, call for an equal right that implies the absolute democratization of fundamental rights, especially in countries with poverty. extreme and social and economic disadvantage. However, all this is achieved with the joint effort of the living forces of the communities involved in this process, to assert their rights as an inclusive and inseparable principle of every human being with needs, but also with the capacity to solve problems. within a legal framework consistent with the reality seen from each country. ${ }^{4,5}$

Consequently, government institutions must confront and assertively social chaos, understood as the disarticulation of the role of the State within its functions and the inability of society to solve its problems without the help of the State. Therefore, the State and society must work together synergistically and in accordance with the provisions of the Constitution and the laws derived from it, otherwise, biased political systems will be imposed within it, with the respective abuse of power and social exclusion.

On the other hand, social rights are born after the conclusion of the Second World War, as part of the Social Rule of Law, being an almost immediate consequence of them, the so-called "Human Rights", that is, it is a set of laws, regulations and Legislative norms approved by the congress and / or assembly of each nation, which determine the ethical and political principles necessary for the creation of a legal matrix for the protection and assurance of the minimum conditions for the socio-economic and ecological subsistence of vulnerable populations , be it ethnic or aboriginal groups and any other sector of society, whose local economy does not allow them to satisfy all basic needs, due to having a weak economy.

This right implies a cultural and organizational philosophy of individuals, since man as an individual being is incapable of subsisting without the help of his peers, even of satisfying the essential requirements for its continuation in social life, therefore, the state must guarantee their rights as entities organized in society, such as: access to public health, free education and any other contractual and / or labor agreement for the benefit of the families of the employees and unions that make life in the corporations.

According to the above, social law is based on an axiological and praxiological matrix that allows the active participation of social actors to engage the contending actions towards "social freedom", which is nothing more than decision-making for the benefit of society, and thus create direct communication channels through community and / or social leaders, so that the right to guarantee them prevails in an equitable manner.

All this translates into a better quality of life for citizens and absolute well-being from the psychological and family point of view, allowing the improvement of the productive apparatus of a nation at the local, regional and national levels. In this sense, the true Social State is concerned with compliance with the constitutional legal framework, because everything lies in society. The State itself is made up of the different social masses and the paradigmatic ideology of its members. In turn, society emerges as the ties between it and the State are strengthened, this translates into a gradual development of social welfare and decision-making regarding family socioeconomic stability.

As society advances, it becomes more structuralist and dependent on the state that exercises political power, therefore, when political power cannot control the social masses, rebellions occur that can lead to the rise of the proletariat with the consequent fall of 
the government. In this sense, the state and society must seek effective mechanisms for equal access to opportunities, duties and rights throughout the social sphere. Hence, the importance of the State-Society binomial in the construction of assertive policies for the implementation of laws and regulations that allow a stable subsistence and coexistence between both parties.

Therefore, fundamental and social rights are of vital importance for constitutionality and organized survival, social structure and the articulation of man as a superior individual in the biosphere. Likewise, they are intertwined by the inalienable nature of the human being as a conscious entity of its own reality and with the ability to seek a synergy with the Social State to satisfy basic needs without prejudice to their peers and to the socio-economic human activities of the daily life in the surrounding society.

According to the above, the objective of this article was to expose the antecedents, concepts, classification and importance of fundamental social rights in the world of Law and for a contemporary society in search of the vindication of human dignity as a way of life and family sustainability. For this, the following questions were formulated:

- What relationship does the evolutionary historical antecedents of social rights have with their current situation?

- What is the importance of the characterization of human rights?

- What is the community importance of social rights?

\section{Methodology}

A documentary analysis was carried out on the object of study, through a discrimination of scientific articles indexed in various electronic repositories and institutional documents, which provided a broad vision on the subject in question, based on various authors and the researcher's own opinion.

\section{Evolution of Fundamental Rights Regulations}

Evolution as a concept, refers to those gradual processes derived from changes in any system, which allow its development, with a capacity for continuous feedback. This means that any natural or artificial system must have the ability to interact with its external environment, which will cause changes in its internal environment, which will lead to continuous restructuring in the medium or long term.

This term can be coined to any field of science, since it is universal and applicable to any context, including Law, since laws derive from continuous social processes and they represent the response to such events. Therefore, the laws are recreated in history and in the way man thinks and acts.

The history of humanity is embodied in a series of events that have left traces during its evolutionary process. This has allowed us to see the consequences of our individual and collective actions, being the basis for cementing new ideas in tone to our rights as human beings, and the way to enforce them rationally for all.

For example, events such as the First and Second World War, gave an important setback to our fundamental rights, since the right to peace and freedom is one of the most fundamental universal fundamental rights for the life of man in society. Later, the man understood that the authoritarian force represented by firearms is not the most assertive solution in the confrontation of powers. Even the United Nations was created after these events, where the majority of the countries of the planet came together to create bonds of brotherhood, beyond any doctrinal difference between the members that comprise it.

Freedom as a fundamental right contains a series of ethical, religious, legal, ethnic connotations, among others, that call for introspective reflection on the human being as a sentimental and social entity. The cultural conception of freedom is diverse according to the culture where the term is extrapolated. But despite this, it has something in common, and it is respect for the other person without our decisions violating the rights and duties of others. This translates into full satisfaction, which is equal to peace and freedom.

Even freedom is reflected in history as a political and social right, since the conquests had as their primary objective, to free themselves from the yoke of their oppressors and to abolish slavery in which many countries found themselves, especially in the 
American continent with the arrival of Europeans. Where each people could decide their destiny, without others making the decisions for them. This was called "sovereignty", which today several nations still dispute their freedom to decide as innate sovereign peoples.

Fundamental rights have transcended the borders of our mind, towards a conjunctural cause where philosophical currents of life very diverse culturally speaking converge, where the dominance of world powers collide to exercise their rights, some more than others. Also internally in society conflicts arise emanating from the freedom of some groups that seek, at whatever cost, to implement their philosophy of life on the rest of the community.

This has resulted in internal civil wars, which more than freedom seek the oppression of the weakest. We live in a heterogeneous world by nature, but this does not imply the impossibility of living as clearly individualistic and self-centered beings. We have the right to freedom since we are born into a society that, no matter how many problems it may have, we must seek the peaceful resolution of the conflicts arising from the de-virtualization of freedom as a fundamental right. ${ }^{9}$

However, it should be noted that the restitution of fundamental rights as a doctrine of life, is limited to a citizen conscience impregnated in the egalitarian desires and individual and collective improvement of the population. Here we enter a high point, because the value of the ethics of the individual enters, as a form of human expression, since as our conscience evolves, so will our actions and decisions regarding our fellow men. Even from here the origin of Legal Ethics is derived as a sub-discipline in Law.

Ethics injects an added value to fundamental rights, because it tries to ensure that the procedures for the implementation of these rights are in the best possible way, this implies: 1) recognizing cultural differences as part of the human heritage of each nation, 2) guiding adequate policies that from the State promote the full participation of citizens, at any time that they consider that their duties and rights have been violated as part of the cultural heritage of a country, 3) promote the scenario for democratization and equal opportunities in decision-making on constitutional guarantees in economic and social matters. This implies accessing and creating employment opportunities to satisfy basic subsistence needs and the incorporation of humanitarian aid for the most vulnerable.

However, it is necessary to reformulate the policies of access to family economic income, this being a tireless struggle in the poorest regions to be able to access basic services and dignify the family as a cell of society. In this sense, the rule of law must jointly guarantee the free right to social satisfaction of the members of the communities. As is known, capitalism demands monetary acquisition as a means of subsistence and acquisition of basic necessities. ${ }^{10}$

All this is possible, when legislative norms and legal ethics point towards the dignity of the human being, as the apex of the pyramid of needs and the rights of man to be staggered within a relatively unjust society with the most unprotected of the society. In fact, the norms referring to International Law are clear regarding this issue, since they are universal and in all countries each Constitution has as a political and social principle, the rescue of the dignity of man, as a fundamental piece of society.

In this way, fundamental rights come to rescue life and everything that it embodies, as a principle of human sustainability, where all the norms of the legal order in the constituent and international state order, seek the positioning of man as the greatest. importance in the world. It is necessary to understand that while the living conditions of the human being improve, our conception of the State as the executing entity of government decisions will change.

I consider it necessary to fully apply the norms on Human Rights, they are well defined and delimited. Unfortunately, corruption and a lack of legal ethics obscure the actions of the agencies in charge of applying them. The legislative sphere at the global level must consider concrete actions that prevent the lowering of the standard of living of citizens. Access to employment and basic services are fundamental rights to perpetuate life, we operate in a very consumerist world and the globalization of markets drags people into poverty, because paradoxically, 
the modernization of life is the privilege of a stamp of people belonging to a devastating political elite of the fundamental principles of human dignity. ${ }^{10}$

Consequently, human rights are inalienable by nature, since citizens deserve respect for life and the ideal conditions for maintaining it. Man is born free in the broad sense of the word and they must continue to be free until their death, and with the same egalitarian conditions regarding their rights and duties. ${ }^{11}$

All under a normative regime of harmonious coexistence and respect for the nature that surrounds us and for the rest of the people, understanding that there should not be any racism or xenophobia, When we disrespect another person, we violate their right and our own, why not we are fulfilling the sole purpose of fundamental rights, freedom of both expression and decision. Always remembering the universality of the same and does not renounce it for any reason.

As long as there is no equity in economic globalization, we will continue to affect fundamental rights as a principle of social organization and citizen coexistence. The State must guarantee the perpetuation of the rights of citizens, in accordance with International Law and the guidelines emanating from each National Constitution. These rights suppose a supremacy of human well-being above any other, of course without putting at risk the resources that man needs to survive.

\section{Definition of Social Rights}

From legal practice, social rights originate to complement fundamental rights, since they are implicitly related. Fundamental rights are established for the protection of man, but this, in turn, forms the society in which we live today. ${ }^{12}$

The fundamental social rights are indispensable rights of the people, which demand the intervention of the public powers for their execution, respect and protection. If the fundamental social rights of individuals were in the hands of themselves, then it would not make sense for the existence of an Executive or Public Power for these rights to be positively acted upon by society, although in many occasions, it is the same Power Public or State who curtails these rights, and therefore defenses arise by the same individual or by third party defenders of society, who seek to enforce fundamental rights. ${ }^{13}$

They have been called fundamental social rights or fundamental social rights, because they refer to rights of personal ownership to protect human dignity and people's living conditions. Theoretically, fundamental rights are framed within economic and cultural rights, but it is social rights that dignify human life and guarantee the good life of the individual, while other rights take a secondary role in order to give effect to the human life and are acquired under other criteria. Social rights must be guaranteed and protected by the Public Power. ${ }^{14}$

Thus, not all fundamental rights are fundamental social rights; Fundamental social rights are all those that guarantee a dignified development to the individual and that are also strictly necessary to function in society and guarantee their good living. Although the cultural and economic aspects may represent a fundamental need for the human being, they are not strict elements for the dignified development of a person's life, and this can change from society to society. In other words, fundamental social rights are all those that guarantee the free development of the personality.

Fundamental social rights are subjective rights, for the reason that these are expressions and manifestations of the individual's own dignity, but that they must be framed in a legal plane for their protection and positive action by the State, whether these are public manifestations or private. Fundamental social rights are the basis of every constitution and support the social and Democratic State of Law, therefore, they are not political goals, but rights that are enforceable and untouchable before any court, if they were to be violated.

They represent the pillar of a nation, they are not negotiable and all the budgetary, political and State provisions must be given for their fulfillment and guarantee, otherwise the atmosphere in which society lives and the State that represents them would be a chimera, one would be talking about a nation injured in its dignity and development. 
As they are fundamental rights, they are rights linked to all Public Powers, that is, the Legislative, Executive and Judicial Power, they must guarantee and execute them in their daily lives for the entire society. The Legislative Power must guarantee the recognition of these rights, while the Executive Power must promote and execute them throughout society and the Judicial Power must protect their realization and effectiveness. The guarantee of fundamental social rights can be affected by social situations in nations, therefore, the Public Powers must fight to allow a minimum effectiveness of the same, otherwise there will be a break in the stability of the life of each individual belonging to that society.

Guaranteeing fundamental social rights implies managing peace, democracy and social freedom. When these rights are violated, then public order is broken and society in danger. From the above, the importance of manipulating fundamental social rights, such as subjective rights linked to Public Powers that work towards a dignified life for the individual. ${ }^{13}$

With the reflection of the previous paragraph we immerse ourselves in a debate on the delimitation of fundamental social rights, because there is an attempt to define fundamental social rights, as only individual rights and not framed at the social level, but it turns out that both rights Individuals such as social rights start from the same root as fundamental rights, because simply an individual belongs to a society. Individual rights must guarantee the positive development of the personality, while social rights must guarantee a dignified life to the person in society through the Public Powers.

It should be noted that fundamental social rights are not collective rights, they are rights applied individually by a community, that is, they have a collective impact. Therefore, each individual must be linked in order to exercise positive personal development and achieve true freedom in society.

From all the above it follows that fundamental social rights are of crucial importance to guarantee social change, that is, the creation and development of a more just society, where inequality is reduced, where social justice is applied and a atmosphere of freedom and peace. This is the tip of the iceberg in our society, not only in our days, but since the entire history of humanity. The desires of man go towards a new horizon full of opportunities that allow him to emerge for the benefit of himself and his families.

Fundamental social rights are relevant because of their urgency for the individual. That is, they refer to the level of importance and impact on the development of the individual within society and as an individual person. Therefore, fundamental rights are linked to the need and urgency of the person to achieve a dignified life and a stable personality development. ${ }^{15}$

From the foregoing, it is highlighted that fundamental social rights are supported, among other things, in equal or non-discrimination. It is necessary that all individuals in a society have equal opportunities to live with dignity, that there is no discrimination against them in order to develop. With these elements of equality, democracy and freedom are born and the creation of an environment of peace.

The elements envisioned in the previous paragraph create the ideal legal framework for a lasting and harmonious coexistence, this has become difficult in some regions of the planet, due to the fact that democracy, peace and freedom are repeatedly violated, without taking into account the dire consequences of negative human actions against himself. It is important to reach lasting agreements in these situations, human rights demand specific actions to guarantee life above anything else, and it is the responsibility of the State initially, if it cannot ensure peace in the affected territory, the authorities are resorted to. international organizations to try to recover it gradually, without many drastic consequences to regret. ${ }^{16}$

Despite the aforementioned, there are criticisms based on the concept of fundamental social rights supported by equality, since these would be viewed as guarantees for citizens, if it is legally spoken. Hence, many other scholars on the subject mention the need to work on these rights as subjective to prevent them from being manipulated as patrimonial rights. ${ }^{17}$

It is important to note that the same man creates the laws and the regulatory mechanisms for their 
applicability, within a legal framework at the state and local level. However, when the rigor is not adequate, the man diverts his attention from the pillar that supports these laws and functional adulterations of it are committed, in order to obtain extra benefits supporting the actions through social rights. We are all ordinary citizens, whether or not we have a direct relationship with state entities, and we do not take advantage of advantageous situations to violate the rights of others.

This legal connotation is justified and supported at the state and international level. Fundamental rights can be discussed in the International Court of Human Rights, as the last resort to reach agreements between the affected parties, this reflects the social relevance of a dignified life and the commitment of the rule of law to enforce such rights. It is imperative to highlight the human value of equity, dignity and desire to improve in an increasingly fragmented society. ${ }^{17}$

In conclusion, fundamental social rights are legal elements whose denial leads to social imbalance and the breakdown of human dignity. Fundamental social rights are subjective rights of special relevance of a positive nature, on which the freedom and democracy of a nation depend.

Fundamental social rights are supported by positive actions, as well as negative actions, that is, like all fundamental rights, social rights are heterogeneous, have actions and omissions. Individuals can appeal to their rights, but without forgetting their duties. It is an ethical and philosophical principle as a standard of life for all men without distinction. It is worth mentioning that only the same man has the power to change our society and move towards a culture of peace, solidarity with those who need it most and the exchange of knowledge and experiences, to strengthen the normative mechanisms of these rights, for a more rational world, tolerant and understanding.

\section{Characterization of Social Rights}

Due to the legal heterogeneity presented by social rights, legal scholars have characterized social rights within the following classification: individual ownership rights and benefit rights. ${ }^{16}$
The right of individual ownership, refers to the figure of the citizen as a thinking being in himself, that despite living and developing in a community, he may or may not share the demands of the rest of the community. For this reason, social rights cannot be taken into account as a collective right par excellence, because it limits and undermines the critical thinking of the person and leaves aside those people who do not belong to a specific group. In addition, they have a subjective nature by their own nature, each person thinks and acts differently, so their claims and ideas vary from one citizen to another. In this sense, it can be said that these rights are strictly limited to each person, since despite adhering to the principle of equality, not all are in the same socio-economic position, that is, some people may be vulnerable in said situation, so they have the right to demand from the state a possible solution to their situation of deprivation, or even from a third person to help them get out of such a scenario. ${ }^{18}$

Therefore, only those who go through a bad situation worries about themselves to get out of it, because in this way they seek to satisfy their basic needs. An example of a disadvantageous situation for an individual can be: education, work, access to health, social security, among others. In this way, each person demands the effective fulfillment of their rights, based on the needs of the moment or the total lack of any of them. Consequently, when some of their rights are violated, the subject feels violated and / or affected by said situation, having full freedom to express to that person or to the State, if required, their right to petition for such demand.

This point is of vital importance, in Colombia and other Latin and European countries, citizens have the so-called "right of petition", when some of their fundamental social rights have been violated and the State is obliged to give an answer, already It is positive or negative regarding the petition issued by the citizen. It should be noted that regardless of the request made by the subject, he cannot expect that the answer will be positive, because sometimes the person does not know well the legal framework on the situation that affects him, and believes that he is right, but the law can rule otherwise and obtain a response that does not satisfy its requirement. ${ }^{19}$ 
According to the foregoing, individual ownership rights can only be assigned singularly and not plural, as a result of the heterogeneity of events that may occur in the surrounding environment and the ability of each subject to satisfy their needs. In such a way, that class action lawsuits cannot be taken for this purpose, they must be individually, despite the fact that a number of people are going through the same situation. It is worth noting the relevant importance of the subject-State binomial, as a mechanism of action in the applicability of rights when these are violated, it even spends for normative adaptation at the judicial, legislative and state level of the rights and individual guarantees of citizens.

In such circumstances, the State is legally seen as an active entity, because it is obliged to attend to requests from the individual, however simple it may be. This factor is very important, and it is noted with concern that on some occasions the State itself violates the rights of the citizen. This leads to a partiality of the state system, with a consequent disagreement on the part of the people, since they feel that their rights are not taken into account. It must be taken into account that the State is made up of people and is owed to them. However, corruption and the handling of the laws in many cases lend themselves to the progressive violation of social rights, this creates chaos and social rebellion in most cases, especially when the proletariat demands their civil rights and freedom. ${ }^{20}$

The right to freedom is one of the most important and has already been treated previously, as a mechanism of individual autonomy, in which the State must protect it as a civic and moral right of the person who possesses it. This takes on greater social relevance from this point of view, giving it a greater nuance of conceptual and / or theoretical scope for maintenance over time. Despite this, it is necessary to emphasize that this right to freedom has a wide legal margin, we are not only talking about the vulnerability of freedom to free territorial access or freedom of expression. Freedom involves life itself and the right to its enjoyment in a manner consistent with legislation. ${ }^{21}$

For this reason, ownership rights enclose a legal sphere of great importance for individual and collective coexistence. As we know, despite the fact that it is spoken in the singular in the standard, we also know that man alone cannot survive without the help of another, only that ideas and decisions will never be the same, therefore, they are characterized individually and not collective. ${ }^{22}$

Social rights are also seen as benefits, this means that they are rights of negative actions for the State, because it has to invest money to ensure their protection and the subject's compliance with them. They are called onerous fees. We have an example of this in education, health, among others, which are fundamental, but the individual would not be able to enjoy it without the help of the State, especially from the financial aspect. ${ }^{23}$

There are some authors who do not see these benefits rights as negative actions, since it implies a not very humane and limiting vision of social rights, because undoubtedly the State and society must work hand in hand to achieve concrete actions of social benefit, so said authors see it as positive and not negative actions. This positive vision of benefit rights is becoming increasingly accepted, it is that in reality the State for its maintenance needs the acceptance of the people, it is a way of negotiating in a very delicate persuasive way, where both obtain benefits, being the acceptance policy on the part of citizens, one of the best benefits for the State.

The foregoing does not imply giving away everything to the individual, it is a question of seeking joint action mechanisms for the benefit of all, ensuring the rights and guarantees of those involved. This is important, unfortunately the corruption system implemented by the State itself affects the protection of the rights of citizens or consumers. When items of money are assigned for some social work, such as building a public hospital or a school and this money is not used for its purpose or is used partially, it causes the actions of the State to be deconfigured, together with the social discontent of the people, for breach of their rights and guarantees of access to public services. ${ }^{24}$

This relationship implies a series of legislative and / or normative obligations on the part of the State and citizens, that is, it is not a win-win of either of the two parties, but rather to get along in a cooperative-type relationship where both earn benefits, and at their own expense. Once, the State gains followers and 
they can promote their products or ideas to society, I understand that the citizen has some duties to fulfill in an hourly manner without affecting the operation of the State, so that the person is not restricted in their social rights.

Government policy, social rights, and citizen obligations move like chess pieces, through political, psychological and social persuasion strategies. However, it is necessary to put all these considerations on the human level, to avoid falling into corruption, lack of moral ethics, social discontent and public chaos. It is a bit difficult and incoherent that there are rights that clearly promote negative or positive actions, both the State and citizens must contribute their share of social responsibility for the synergistic progress of society ${ }^{25}$

The important thing about this is the collaboration of the State-Society binomial to comply with social rights at the local and international level, as guarantees of the same towards a more egalitarian world. This situation should be more noticeable in the most unprotected and vulnerable areas, where the State is incapable of complying with social rights, taking as a premise the lack of economic resources to honor them. This implies a conceptual, moral and praxiological interdependence of the State power and the Citizen Power in the construction of a social fabric capable of maintaining a dignified relationship and in accordance with the estates emanating from the legislation on social and / or human rights, which favor a healthy interaction of the members involved.

This situation is reflected in those societies that, despite their difficulties (which there will always be, even in the best state systems in the world), live without major problems, because they have at least the following conditions: access to public and private education, living wages that allow the working class to access public services and pay for their food, certain contractual and / or labor benefits, a solid currency, low inflation, free and private health, with financing possibilities in the private part, level of low corruption, among others. It may sound like a fairy tale, although in many countries some or all of the conditions exist, purchasing power and the level of corruption are essential for the maintenance of lasting human relations and for the benefit of the protection and guarantee of social rights.

\section{Social Rights as Benefits Rights}

Fundamental rights or also known as human rights can be classified under different criteria. According to the historical criterion, human rights can be classified according to the moment in which they were vindicated and recognized in the Constitutions, giving rise to generations of rights. The first generation of rights is made up of civil and political rights, which were vindicated at the end of the 18th century and added to the first liberal Constitutions, highlighting the right to life, liberty and security, the right to liberty. expression. Within the second generation are economic and social rights, which were considered thanks to the demands of workers supported by revolts of the socialist and communist parties in the mid-nineteenth century. These rights were registered within the Constitutions as the right to work, education and social security. When speaking of third-generation rights, heterogeneous rights recently claimed are dealt with and that owe their origin to social and technological changes, such as the right to the environment, the right to information and the right to peace ${ }^{26}$

In this section of the research, the second generation rights or social rights will be discussed and deepened, which were recognized from the Second World War in various Democratic Constitutions. International treaties also included this type of rights within their consideration and the Universal Declaration of Human Rights was postulated in 1948, and even the United Nations World Organization takes into account and highlights the importance of fundamental social rights in 1966.

Supported by the legal nature of fundamental rights, a distinction is made between the rights of defense and the rights of provision. The former are rights to negative actions by the State, their objectives are to preserve situations of great importance or vulnerability from State intervention. While the latter are rights to positive actions of the State ${ }^{26}$

The rights of benefits are classified as: the rights to protection, where the State protects the individual against interventions by third parties; the rights to organization and procedure that have more to do with judicial procedures; the rights to benefits in the strict sense, which are rights that the person has against the State. 
Talking about fundamental social rights, such as the right to work, housing, social security or education, we are talking about rights of benefits in the strict sense, therefore they are recognized as social rights of benefit.

The social rights of provision stand out for their difficulty in the face of legal effectiveness, that is, despite the recognition and inclusion of these within the Constitutional charters, the effective guarantee of these is difficult. To achieve this guarantee, it is necessary for the State to have an unlimited economic base to support them, which is difficult when a market economy is managed. This particular aspect of social benefit rights has led to great debates about the distribution of wealth and the thesis about whether these rights are really fundamental due to their lack of aptitude for their effectiveness. ${ }^{27}$

Therefore, the question arises if the social rights of provision are really fundamental rights. Many scholars answer that the social rights of benefits will be fundamental if they constitute subjective and constitutional rights. For this, within the subjective scope, the rights of benefits must form a triad between the holder, the State and a positive action of the State. The owner, by having a right against the State, must exercise a positive action on the owner, achieving competence to legally enforce the right. This judicial imposition of fundamental social rights is the characteristic that places them at the same level as the rights to benefits, but does not give it an absolute character, that is, they may conflict with other rights or constitutionally protected goods and in this case, the legal entity must weigh the rights and determine which one prevails. ${ }^{28}$

In the case of social rights of provision, these are shielded with the thesis of factual freedom, that is, there is no way to displace or belittle these rights by others, they depend essentially on state activities of provision.

On the other hand, the social rights of provision, are rights of freedom that allow the autonomous development of the individual, since a man is free as long as his main needs are covered and met.
Now, the social rights of benefit have the character of freedom, but which of them are really fundamental. The answer to this question will depend on the weighting and importance of each legislator within the Constitution. But, as already mentioned in previous paragraphs, these rights can be displaced by others, therefore, it will depend on how the State can give them financial support and justify that support before a Court. ${ }^{29}$

The social rights of provision are considered fundamental as long as they are recognized in the Constitutions and are judicially protected by the Public Powers. Social benefit rights are framed within the fundamental rights according to the weighting model, such as prima facie rights, which makes them definitive rights.

An individual has a definitive right when the principle of factual freedom has a greater weight than the opposite formal and material principles taken as a whole, which is called minimum fundamental social rights. However, the fact that these rights are final does not mean that they are judicially justified. They must have a concrete role of justiciability and stipulated within the Constitution.

In most cases, democratic Constitutions do not allow for the rights to a vital minimum or guaranteed minimum resources, however, in recent years, some countries and Constitutions, due to social and political circumstances, have begun to establish aspects of minimum guarantee on fundamental rights, so that the individual has the protection of their social rights in special situations.

The right to a vital minimum is woven thanks to the connection between the right to a decent life and the Principle of the social State of Law. These rights must be guaranteed even when they are not legally justified or constitutionally included.

In the Universal Declaration of Human Rights in 1948 , the rights to a vital minimum are recognized, which allow the dignified development of the personality and life of the individual. These minimum vital rights are recognized as all those rights that must be guaranteed as main or fundamental in the 
life of an individual, and there may be many more. They are rights that must be freely available to human beings to meet their basic and vital needs30 There are many principles to justify the existence and guarantee of the rights to a vital minimum. In the first place, every human being has the right to really enjoy their freedom, for this it is necessary that they have a minimum of economic security, so as not to be in a state of need. On the other hand, the right to a vital minimum is the principle of equality. This principle should not be given only by the prohibition of discrimination, but by the right to material equality, that is, that we all have equality of existence.

In a market economy, the State must guarantee the non-existence of marginality and allow all citizens to develop with dignity in all areas of life. To achieve this guarantee, economic relations must develop freely, ensuring a minimum of resources for all members of the community. Individual capabilities and economic laws of supply and demand will depend on this guarantee, which will determine the level of enjoyment of goods and services among citizens 31 Within these fundamental rights of freedom and equality, a third right of modern times arises, such as solidarity to overcome differences and discrimination, so that every citizen is also compassionate towards others and thus the whole society is stable. In their collective way of life.

The guarantee of social benefit rights is framed in the following aspects: ${ }^{32}$

1. The problem of its legal value: In most cases there is a discussion about whether these rights are really fundamental, which gives them a character of diminished rights or in formation. These rights are always added in an ethereal chapter of discussion, but finally they are always recognized as fundamental minimums for the development of human life, in a constitutional way.

2. Objective dimension of the benefit rights: These social rights of provision include all the Public Powers and are legally and constitutionally recognized.

3. Subjective dimension of benefits rights: The social rights of provision are constitutionally recognized with their maximum protection and must be positively executed on every individual.

Therefore, fundamental social rights are of great relevance to be included in every Constitution and therefore that each institution or State guarantees their excellence, jurisdictionally and constitutionally, but also in an ordinary and minimal way to accommodate a dignified development of its citizens, to a free and peaceful nation. ${ }^{33}$

\section{Conclusion}

Social rights from the conceptual point of view have an implicit connotation of the sense of solidarity, some researchers admit that equality and solidarity go hand in hand, since one depends on the other, and in this sense, it is correct to believe this by several reasons: 1) the principle of equality as a moral and social value, implies giving the opportunity to those who are disadvantaged, 2) at this point we enter solidarity as an essential human value for coexistence, 3) we cannot leave behind to those who need help from third parties, 4) this implies satisfying all the needs and / or deficiencies of the affected people, but if creating mechanisms for humanitarian overcoming, this does not mean giving away the necessary requirements to those people in vulnerable situations for life, but if they offer tools that help them overcome the socio-economic crisis, 5) national and international organizations have created various e social action to help people in disadvantage and extreme poverty, example of them are the United Nations and other civil associations of humanitarian aid.

What is described in the previous paragraph, has from my judgment a principle of legal and / or social invisibility and this is supported by other authors, who justify their reason in International Law, who advocates fundamental and social rights as one, without classification some, since they are unequivocally related and ratify the concept of equality within them, without legal distinction, because in the end, the rights go towards the socio-economic and substantial improvement of man and not to the hierarchical diversification in the legal framework, that is, in the opinion of some 
researchers, this classification creates certain conceptual confusions, which, in turn, affects their applicability.

\section{Acknowledgement}

We acknowledge all the authors whose works were sightedhere.

\section{Funding}

The author(s) received no financial support for the research, authorship, and/or publication of this article.

\section{Conflict of Interest}

The authors do not have any conflict of interest.

\section{References}

1. Sánchez, A. (2014). Concepto, fundamentos y Evolución de los Derechos Fundamentales. Eikasia. Revista de Filosofía, (2): 229-235.

2. Tetyana, B. (2020). Some problema aspects of implementation and protection of property right of spouses. Journal of the National Academy of Legal Sciences of Ukraine; 27(1).

3. Cruz, E. (2002). Derechos Humanos, Estado de Derecho y Constitución" Criterio Jurídico Garantista, (2): 62-70.

4. Aguilar, G. (2010). Derechos FundamentalesDerechos Humanos. ¿Una distinción válida en el Siglo XXI? Boletín Mexicano de Derecho Comparado, (127): 15-71.

5. Boele-Woelki, K. (2019). The commission of European family law: Taking stock after almost twenty years. Journal of International and Comparative Law, 6(2), 233- 244.

6. Simpson, M. (2018). Assessing the compliance of the UK social security system with the state's obligations under the European Social Charter; EHRLR 18(4): 745 https://doi. org/10.1093/hrlr/ngy030

7. Castro, E., Restrepo, O., García, L. (2007). Historia, concepto y estructura de los derechos económicos, sociales y culturales. Revista Estudios Socio-Jurídicos, (9): 77-100.

8. McKeever,. G., Simpson, M., Fitzpatrick, C. (2018). Destitution and paths to justice. Joseph Rowntree Fondation. Legal Eduycation Fondation. Pp: 11-26.

9. Simpson, M. (2018). Social rights, child rights, discrimination and devolution: Untangling the web. Journal of Social Welfare and Family Law, 40(1), 3-20

10. Fazio, F. (2018). El concepto estricto de los derechos sociales fundamentales. Revista Derecho del Estado, (41): 173-175.
11. Villalon, P. (1989). Formación y evolución de los derechos fundamentales. Revista Española de Derecho Constitucional, (1989, 25): 35-40.

12. Martínez, E. (2008). Los Derechos Sociales: Una reflexión a propósito de la sentencia Rol 976 del Tribunal Constitucional. Nomos, (2): 275-290.

13. Rodríguez, J. (2015). Sobre el concepto de los derechos sociales fundamentales. AFDUC, (19): 115-117.

14. Rojas, N. (2011). Los Derechos Económicos, Sociales y Culturales y la Justicia Constitucional Latinoamericana" Revista Estudios Constitucionales, (9): 65-100.

15. Pachot A. (2010). Propósito del carácter fundamental de los Derechos Económicos, Sociales y Culturales. Una Mirada desde la Doctrina Comparada y la expresión del Ordenamiento Jurídico Cubano" Revista Estudios Constitucionales, (8): 65-118.

16. Quesada. L. (2019). El constitucionalismo social y los objetivos del desarrollo sostenible (ODS)" Lex Social: revista de derecho social, (1): 13-40.

17. Salazar, S. (2013). Fundamentación y estructura de los derechos sociales. Revista de Derecho, (1): 69-89.

18. Sáenz, E. (2003). Estado social y descentralización política”. Una perspectiva constitucional. Una perspectiva constitucional comparada de Estados Unidos, Alemania y España" Civitas: 12-13.

19. Pérez, A. (1997). Estado constitucional y derechos de la tercera generación. Anuario de Filosofía del Derecho (14): 545-550.

20. Danzinger, C. (2008). Los Derechos Económicos, Sociales y Culturales. Limitaciones y Proyecciones. Nomos, (2): 
59-90.

21. Cossio, J. (2016). La ineficiencia de los derechos sociales. Hechos y Derechos, (32): 10-20.

22. Atienza, M. (2006). El Derecho como argumentación. Revista de Derecho, (1): 285-286.

23. Jara, M (2013). La plena igualdad como garantía de los derechos sociales y la proyección de la solidaridad = Full Equality As a Guarantee of Social Rights and Projection of Solidarity". Lex Social Revista De Derechos Sociales, (2): 79-102.

24. Sastre, S. (2001). Hacia una teoría existente de los derechos sociales. Revista Estudios Políticos, (112): 253-260.

25. Herreros, J. (2011). La justiciabilidad de los derechos sociales. Lex Social, Revista de Ios Derechos sociales, (1): 10-20.

26. Henao, S. (1991). Evolución y origen del concepto de Estado Social incorporado en la Constitución Política colombiana. Ratio Juris, (14): 1-5.

27. Contreras, P., García, G., Díaz, J., Villanuev, A, (2010). Informe en Derecho Presentando ante el Tribunal Constitucional en el Proceso de Inconstitucionalidad del Artículo 38 Ter de la Ley NN 18.933" Revista Estudios
Constitucionales, (2): 633-674.

28. Figueroa, J. (2009). Justicialidad del Rol de las Cortes Haciendo justiciables los Derechos Económicos, Sociales y Culturales, en particular, el Derecho a la protección de la Salud" Revista Chilena de Derecho, (2): 313-342.

29. Riveros, D. (2010). Los derechos económicos, sociales y culturales como derechos subjetivos: una visión estructural. Revista Derecho del Estado, (24): 29-43.

30. Martínez, M., Sosa Y. (2018). Patrimonio familiar, un derecho al mínimo vital como garantía social. Inventio, (27): 1-5.

31. Dueñas, O. (1999). Conclusiones de la investigación sobre derechos prestacionales. Estudios Socio-Jurídicos, (2): 1-3.

32. Carmona, E. (1992). Las normas constitucionales de contenido social: delimitación y problemática de su eficiencia jurídica. Revista de Estudios Políticos, (76): 1-3.

33. Noriega, H. (2009). Los derechos económicos, sociales y culturales como derechos fundamentales efectivos en el constitucionalismo democrático latinoamericano. Estudios Constitucionales, (2): $143-2000$. 